\title{
Hematopoiesis Activity of Sambucus javanica on Chloramphenicol-induced Aplastic Anemia Mouse Model
}

\author{
Wira Eka Putra ${ }^{1, *}$ and Muhaimin Rifa' ${ }^{2}{ }^{2, *}$ \\ ${ }^{I}$ Department of Biology, Faculty of Mathematics and Natural Sciences, State University of Malang, Indonesia \\ ${ }^{2}$ Department of Biology, Faculty of Mathematics and Natural Sciences, Brawijaya University, Indonesia
}

\begin{abstract}
Hematopoiesis has a pivotal role in the maintenance of body homeostasis. Ironically, several hematological disorder caused by chemicals, drugs, and other environmental factors lead to severe bone marrow failure. Current treatments like stem cell transplantation and immunosuppression remain ineffective to ameliorate this diseases. Therefore, a newtreatment to overcome this entity is necessary, one of them by promoting the usage of medicinal plants. Thus, this study aimed to evaluate the hematopoiesis potency of $S$. javanica berries and leaves extracts in chloramphenicol (CMP)-induced aplastic anemia mice model. In this present study, several types of blood progenitor cell such as TER- $119^{+} \mathrm{VLA}-4^{+}$erythrocytes lineage, Gr- $1^{+}$granulocytes, and $\mathrm{B} 220^{+} \mathrm{B}-$ cell progenitor cells were evaluated by flow cytometry analysis. Accordingly, we revealed that $S$. javanica berries and leaves extracts significantly promoted TER $-119^{+} \mathrm{VLA}-4^{+}$erythrocytes lineage and $\mathrm{Gr}-1^{+}$granulocytes after exposed by CMP. Thus, these results suggested that $S$. javanica berries and leaves extracts might have hematopoiesis activity in CMP-induced aplastic anemia mice model.
\end{abstract}

Keywords - Aplastic anemia, CMP, hematopoiesis, medicinal plant, S. javanica

\section{Introduction}

Aplastic anemia is the uncommon form of the hematological disorder that characterized by pancytopenia followed with bone marrow failure. ${ }^{1-3} \mathrm{~A}$ report revealed the incidence of aplastic anemia is between 1.4 to 14 cases per million people. ${ }^{4}$ Furthermore, the incidence of this entity is higher in Asia compared with West Countries. ${ }^{5}$ Aplastic anemia is clinically dangerous due to the low number of marrow. This rare disease usually associated with other hematological disorder such as myelodysplasia, pure red cell aplasia, and myelofibrosis. ${ }^{6}$

Generally, aplastic anemia is caused by two factors, genetic and acquired. Importantly, it has been revealed that acquired aplastic anemia influenced by environment exposures such as drugs, radiation, viruses, and other chemicals. ${ }^{7,8}$ One of the most common medicine that caused aplastic anemia is CMP. ${ }^{9-11}$ The CPM has been widely known as an antibiotic against numerous infectious

\footnotetext{
*Author for correspondence

Wira Eka Putra, Department of Biology, Faculty of Mathematics and

Natural Sciences, State University of Malang, Indonesia

Tel: +62-341-588077; E-mail: wep.cendekia@gmail.com
}

Muhaimin Rifa'i, Department of Biology, Faculty of Mathematics and Natural Sciences, Brawijaya University, Indonesia

Tel:+62-341-575841; E-mail: rifa123@ub.ac.id diseases. Even though, many studies showed that CMP has toxicity in the hematopoietic system. ${ }^{12}$

Currently, treatments for aplastic anemia include stem cell replacement and immunosuppressive therapy. ${ }^{11,13,14}$ Alongside with this therapy, such supportive treatment also employed such as transfusion, antibiotics, and hematopoietic growth factor. ${ }^{15}$ The most challenging problems for aplastic anemia treatment are a relapse and the clonal evolution to another hematologic disease. ${ }^{16}$ Therefore, the new therapy to overcome this disease is necessary.

The genus of Sambucus is already known as food resources and folk medicine. Sambucus plants are common shrub with a heightapproximately up to $7 \mathrm{~m}$ and are found in almost continents. ${ }^{17,18}$ People usually used several parts of Sambucus including berries, flowers, and bark for particular purposes. ${ }^{19}$ It has been reported that Sambucus contained massive numbers of bioactive compounds such as anthocyanins, procyanidins, triterpenoids, flavonols, quarcetin, kaempferol, rutin, and cathecin. ${ }^{18,20,21}$ Numerous reports also revealed the medicinal advantageous of Sambucus such as antivirus, anti-inflammation, and antidiabetic..$^{22,23}$ Despite this interest, no one to the best our knowledge has studied about the potency of Sambucus toward hematopoiesis. Thus, this present study 
aimed to evaluate the effect of $S$. javanica on hematopoiesis in acquired-aplastic anemia mice model. Finally, we expect the outcome of this report could provide beneficial information about the medicinal properties of S. javanica, especially in hematopoiesis therapy.

\section{Experimental}

Plant materials preparation - In this study, S. javanica berries and leaves extracts were used as herb treatment toward experimental mice. Further, plant materials were obtained from Materia Medica Batu, The Ministry of Health Indonesia. Moreover, S. javanica berries and leaves were proceeded by ethanol extraction. Ethanol extraction is a popular approach to press out the plants' secondary metabolites. Then, $S$. javanica berries and leaves powders were dipped into $70 \%$ ethanol for five days. After macerate filtration, rotary evaporator was employed to evaporate the solvent. Then, final yields stored in the $4{ }^{\circ} \mathrm{C}$ room for the next experiment.

Animal treatment and ethical clearance-Threemonth-old $\mathrm{BALB} / \mathrm{c}$ mice were purchased from Laboratory of Animal, Gadjah Mada University following with pathogen-free authentication. The experimental mice were orally treated with $130 \mathrm{mg} \cdot \mathrm{kg}^{-1} \mathrm{BW}$ of CMP (Sanbe Farma) for two weeks to induce acquired-aplastic anemia, then subsequently followed by oral administration of $S$. javanica berries and leaves extracts with respective doses such as 50,100 , and $200 \mathrm{mg} \cdot \mathrm{kg}^{-1} \mathrm{BW}$ for two weeks. Moreover, this study already passed the ethical clearance by the Brawijaya University Research Ethics Committee, Indonesia.

Immunostaining and flow cytometry analysis - Flow cytometry analysis was performed to evaluate the relative number of particular cell or protein of interest which marked by the antibody. ${ }^{24,25}$ In this study, bone marrow was isolated from femur and tibia of experimental mice. After that, the samples were filtered and resuspended for immunostaining. Further, various cells lineage were observed such as erythrocytes lineage (TER-119 ${ }^{+}$VLA$\left.4^{+}\right)$, granulocytes $\left(\mathrm{Gr}-1^{+}\right)$, and B-cell progenitor cells $\left(\mathrm{B} 220^{+}\right){ }^{26}$ Therefore, several antibodies used in this experiment were mouse anti-TER-119, mouse anti-VLA4, mouse anti-Gr-1, and mouse anti-B220 antibody (BioLegend). FACS Calibur ${ }^{\mathrm{TM}}$ flow cytometer (BD-Biosciences, San Jose, CA) and BD Cell Quest Pro $^{\mathrm{TM}}$ software were employed in this study.

Statistical Analysis-Student t-test was used to perform statistical analysis. Replication of each data set was applied and was shown as mean $\pm \mathrm{SD}$ values. This experiment was carried out the significance level $(\alpha)$ equals to 0.05 .

\section{Result and Discussion}

In this present study, CMP was applied to induce the acquired-aplastic anemia in the experimental mice. Furthermore, S. javanica berries and leaves extracts were used to treat the CMP-administrated mice (Fig. 1). To greater extend, we evaluated the relative number of TER$119^{+}$VLA- $4^{+}$erythrocytes lineage, Gr- $1^{+}$granulocytes, and B220 $0^{+}$B-cell progenitor cells by flow cytometry analysis (Fig. 2).

According to the flow cytometry diagrams, we found that the relative number of TER- $119^{+} \mathrm{VLA}-4^{+}$were decreased in the CMP group. However, after treatment

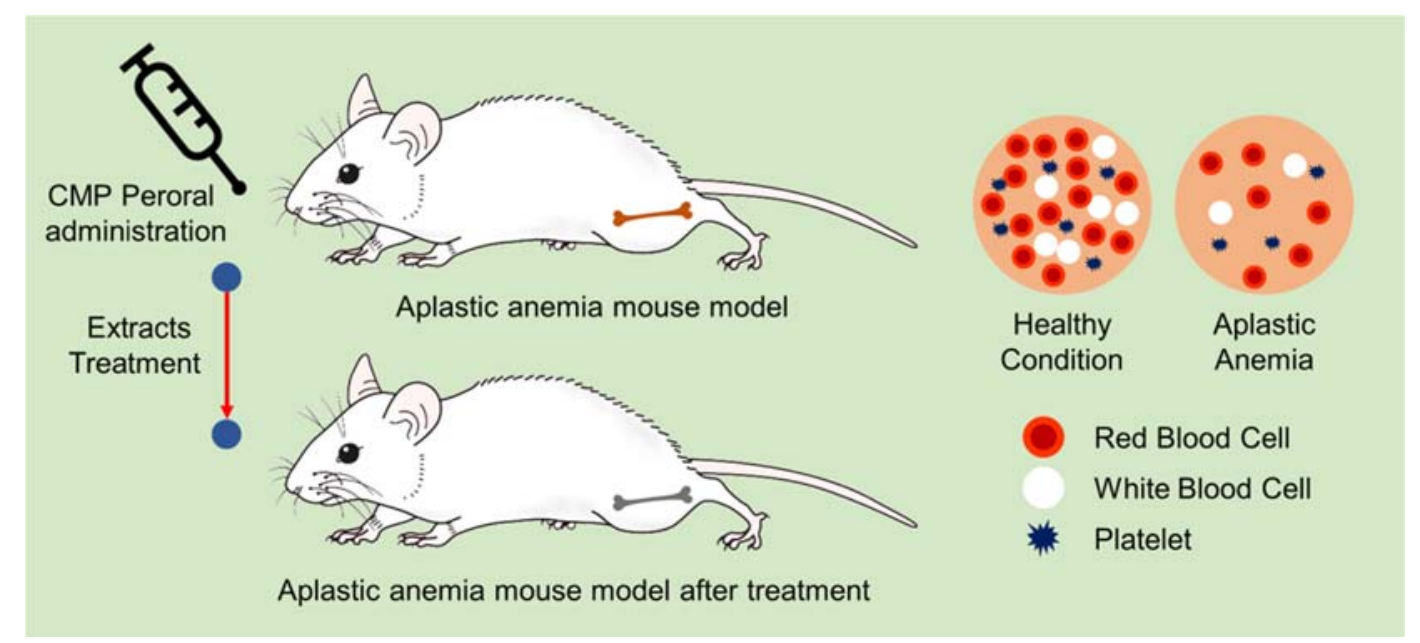

Fig. 1. A schematic diagram showed that CMP administration in BALB/c mouse induces acquired aplastic anemia, nevertheless the bioactive compounds from leaves and berries extracts of $S$. javanica can ameliorate the adverse condition by enhancing hematopoiesis. 

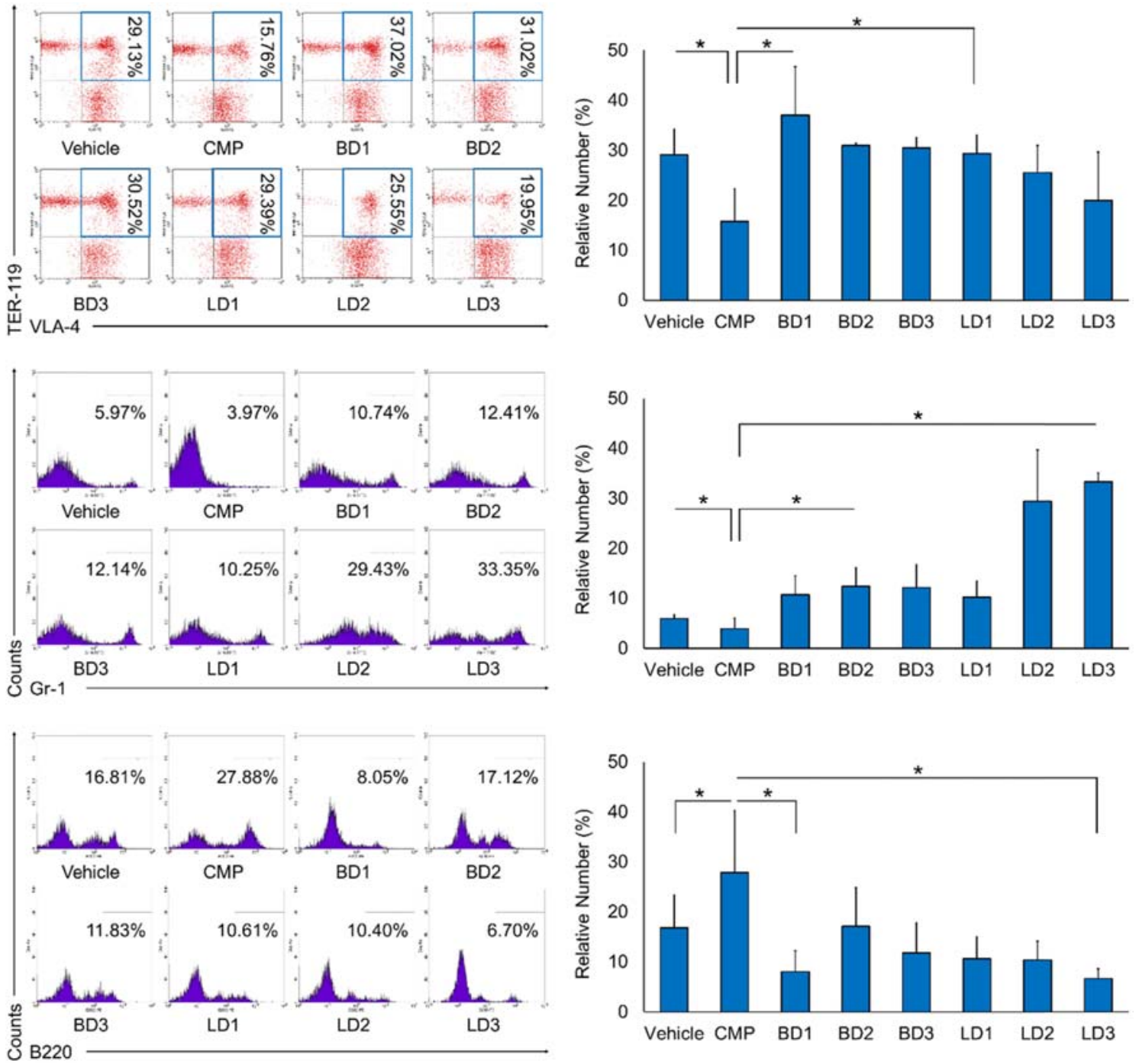

Fig. 2. The representative flow cytometry diagrams show TER $-119^{+} \mathrm{VLA}-4^{+}, \mathrm{Gr}-1^{+}$, and $\mathrm{B} 220^{+}$expression. $S$. javanica extracts promoted the relative number of TER $-119^{+}$VLA $-4^{+}$erythrocytes lineage and $\mathrm{Gr}-1^{+}$granulocytes, while CMP induce the relative number of B220 $0^{+}$ B-cell progenitor cells. The bars are calculation of the relative number TER- $119^{+} \mathrm{VLA}-4^{+}, \mathrm{Gr}-1^{+}$, and B220 $0^{+}$expression. The results were shown as the mean $\pm \mathrm{SD} .{ }^{*} \mathrm{P}<0.05$, indicate significant difference. Treatment group in this study were vehicle, $\mathrm{CMP} 130 \mathrm{mg} . \mathrm{kg}^{-1} \mathrm{BW}$; BD1, CMP 130 mg.kg ${ }^{-1}$ BW + berries extracts 50 mg.kg ${ }^{-1} \mathrm{BW}$; BD2, CMP 130 mg.kg ${ }^{-1} \mathrm{BW}$ + berries extracts $100 \mathrm{mg} \cdot \mathrm{kg}^{-1} \mathrm{BW}$; BD3, CMP 130 mg. $\mathrm{kg}^{-1} \mathrm{BW}$ + berries extracts $200 \mathrm{mg} \cdot \mathrm{kg}^{-1}$ BW; LD1, CMP 130 mg.kg ${ }^{-1} \mathrm{BW}+$ leaves extracts $50 \mathrm{mg} \cdot \mathrm{kg}^{-1}$ BW; LD2, CMP 130 mg.kg ${ }^{-1} \mathrm{BW}+$ leaves extracts $100 \mathrm{mg} \cdot \mathrm{kg}^{-1} \mathrm{BW}$; LD3, CMP $130 \mathrm{mg} \cdot \mathrm{kg}^{-1} \mathrm{BW}+$ leaves extracts $200 \mathrm{mg} \cdot \mathrm{kg}^{-1} \mathrm{BW}$.

with $S$. javanica berries and leaves extracts the trend was significantly increased, especially on dose- 1 of berries or leaves extracts. Similarly, the relative number of $\mathrm{Gr}-1^{+}$ demonstrated the same pattern with erythrocytes lineage sample. The number of $\mathrm{Gr}-1^{+}$were suppressed under CMP induction, but it was importantly promoted in dose2 of berries and dose- 3 of leaves extracts. Otherwise, the interesting findings revealed that the relative number of $\mathrm{B} 220^{+}$was sharply enhanced by CMP induction. Afterward, the $S$. javanica extracts suppressed the amount $\mathrm{B} 220^{+}$ (Fig. 2).
Aplastic anemia is a severe hematologic condition in which the bone marrow failure caused by direct toxicity, metabolite-driven toxicity and immune-mediated damage of hematopoietic stem cells. ${ }^{7,27}$ Therefore, it has been pointed out that the hematopoiesis failure is the most common hallmark of aplastic anemia which was also marked by the significant decreasing amount of all hematopoietic progenitor cells. ${ }^{3,15}$ Hematopoiesis have a pivotal role in producing the components of blood cells. ${ }^{28,29}$ Every mature blood cells are coming from the single lineage, hematopoietic stem cells (HSCs). The 
HSCs have a pluripotent ability which allowed them to develop into several progenitor cells such as myeloid and lymphoid progenitor cells. ${ }^{30,31}$ Therefore, inducing the hematopoiesis to generate blood progenitor cells is one of the therapeutic strategies to ameliorate aplastic anemia.

In summary, we demonstrated that CMP exposures to experimental mice could decrease the relative number of TER- $119^{+}$VLA- $4^{+}$erythrocytes lineage and $\mathrm{Gr}-1^{+}$ granulocytes. A group of researchers showed that pnitrosulfathiazole substances which were known as chloramphenicol derivative causing inhibition of DNA synthesis in marrow stem cell and eventually cell death. ${ }^{10}$ On the other hand, we found that the treatment of $S$. javanica berries and leaves extracts significantly promoted those blood lineage cells (Fig. 2). These findings suggested that the bioactive compounds of $S$. javanica might contributeto enhancing the hematopoiesis activity.

Medicinal plants are the alternative medication for any diseases compared to chemicals drug because it properties with fewer side effects, more adaptive to the human body, and convenient to use. ${ }^{32}$ Generally, medicinal plants contain bioactive compounds such as phenolic, flavonoids, and another plant-derived chemical that used in reparative and regenerative therapy. Several studies already showed that the bioactive compounds of medicinal plants could inhibit the tumor growth and promote stem cell proliferation. ${ }^{33,34}$ It has been noted that iron absorptionincreasing agent is the general mechanism how medicinal plants promote hematopoiesis. ${ }^{32}$ Furthermore, Pawar et al. (2006) showed the effects of several medicinal plants such as Syzygium aromaticum, Cinnamomum zeylanicum, and Salvia triloba extracts induce proliferation and differentiation of dental pulp stem cells. ${ }^{35}$ Moreover, Mendi et al. (2017) demonstrated the hematopoietic activity of Asteracantha longifolia toward bone marrow suppression caused by cyclophosphamide. ${ }^{36}$ Surprisingly, pomegranate juice also showed the protective effect toward blood cells in lead-exposed rats. ${ }^{37}$ Moreover, phitochemicals extracted from olive leaves such as oleuropein, apigenin 7-glucoside, and luteolin 7-glucoside have been shown the hematopoiesis activity by promoting viability, selfrenewal, and differentiation of hematopoietic stem cells. ${ }^{38}$ Other study conducted by Ferri-Lagneau et al. (2012) revealed that bioactive compounds from ginger upregulated the expression of hematopoietic progenitor markers such as gata1, cmyb, and scl in zebrafish model. Furthermore, it has been confirmed that ginger extracts mediate the hematopoiesis via Bmp/Smad pathways by using LND193189 and DMH1. ${ }^{39}$

Finally, in this present study, we revealed that $S$. javanica promoted erythrocytes lineage (TER- $119^{+}$VLA$4^{+}$) and granulocytes $\left(\mathrm{Gr}-1^{+}\right)$after exposed by CMP. Thus, these results suggested that $S$. javanica berries and leaves extracts have hematopoiesis activity in CMP-induced aplastic anemia mice model. Finally, future research needs to emphasize in order to evaluate more details about the specific pathways of $S$. javanica bioactive compounds stimulated hematopoiesis activity in CMP-induced aplastic anemia mice model.

\section{Acknowledgements}

The authors thank the members of animal anatomy and physiology laboratory, Department of Biology, Faculty of Mathematics and Natural Sciences, Brawijaya University. WEP thanks to LPDP (Indonesia Endowment Fund for Education) to support this study.

\section{References}

(1) Gupta, V.; Kumar, A.; Saini, I.; Saxena, A. K. Indian J. Med. Res. 2013, 137, 502-506.

(2) Young, N. S. Hematology Am. Soc. Hematol. Educ. Program 2006, 72-77.

(3) AlKhouri, N.; Ericson, S. G. Hosp. Physician 1999, 35, 46-52.

(4) Maluf, E.; Hamerschlak, N.; Cavalcanti, A. B.; Júnior, A. A.; ElufNeto, J.; Falcão, R. P.; Lorand-Metze, I. G.; Goldenberg, D.; Santana, C. L.; Rodrigues, Dde. O.; Passos, L. N. M.; Rosenfeld, L. G. M.; Pitta, M.; Loggetto, S.; Ribeiro, A. A. F.; Velloso, E. D.; Kondo, A. T.; Coelho, E. O. M.; Pintão, M. C. T.; de Souza, H. M.; Borbolla, J. R.; Pasquini, R. Haematologica 2009, 94, 1220-1226.

(5) Young, N. S.; Kaufman, D. W. Haematologica 2008, 93, 489-492.

(6) Muthukumaraswamy, P. K. Post Graduate Medicine. Bone marrow failure syndromes: An overview; Indian College of Physicians: India, 2004, pp 372-382.

(7) Rao, K. V. Pharmacotherapy: A Pathophysiologic Approach, 9E: Drug-induced hematologic disorders; McGraw-Hill; USA, 2014, pp 359374.

(8) Turton, J. A.; Andrews, C. M.; Havard, A. C.; Williams, T. C. Int. J. Exp. Pathol. 2002, 83, 225-238.

(9) Gavriluț, C. I.; Urian, L.; Petrov, L. Acta Medica Transilvanica 2015, 20, 23-25.

(10) Shukla, P.; Bansode, F. W.; Singh, R. K. J. Med. Med. Sci. 2011, 2, 1313-1316.

(11) Chen, J. Clin. Med. Res. 2005, 3, 102-108.

(12) Yuan, Z. R.; Shi, Y. Cancer Res. 2008, 68, 4875-4881.

(13) Guinan, E. C. Hematology Am. Soc. Hematol. Educ. Program 2011, 2011, 76-81.

(14) Segel, G. B.; Lichtman, M. A. Williams Hematology, 8E: Aplastic anemia: Acquired and inherited; McGraw-Hill; USA, 2010, pp 463-483.

(15) Găman, A.; Găman, G.; Bold, A. Rom. J. Morphol. Embryol. 2009, $50,669-674$.

(16) Young, N. S.; Calado, R. T.; Scheinberg, P. Blood 2006, 108, 25092519.

(17) Kamenjaković, M.; Hadžić, V.; Kulić, S.; Hasičić, S. Food Health Disease 2017, 6, 1-6.

(18) Ho, G. T. T.; Wangensteen, H.; Barsett, H. Int. J. Mol. Sci. 2017, $18,1-17$. 
(19) Barak, V.; Halperin, T.; Kalickman, I. Eur. Cytokine Netw. 2001, 12, 290-296.

(20) Jiménez, P.; Tejero, J.; Cordoba-Diaz, D.; Quinto, E. J.; Garrosa, M.; Gayoso, M. J.; Girbés, T. Toxins (Basel) 2015, 7, 648-658.

(21) Barsett, H.; Aslaksen, T. H.; Gildhyal, P.; Michaelsen, T. E.; Paulsen, B. S. European J. Med. Plants 2012, 2, 216-229.

(22) Badescu, M.; Badulescu, O.; Badescu, L.; Ciocoiu, M. Pharm. Biol. 2015, 53, 533-539.

(23) Groza, M.; Ciocoiu, M.; Bădescu, L.; Bădulescu, O.; Bădescu, M. Annals of RSCB. 2010, 15, 241-246.

(24) Putra, W. E.; Wafaretta, E.; Ardiana, O.; Januarisasi, I. D.; Soewondo, A.; Rifa'i, M. Bioscience Research 2017, 14, 201-213.

(25) Putra, W. E.; Soewondo, A.; Rifa'i, M. Jurnal Biotropika 2015, 3, 42-45.

(26) Putra, W. E.; Soewondo, A.; Rifa'i, M. J. Pure App. Chem. Res. 2015, 4, 100-108

(27) Ogawa, S. Blood 2016, 128, 337-347.

(28) Jagannathan-Bogdan, M.; Zon, L. I. Development 2013, 140, 2463 2467.

(29) Rieger, M. A.; Schroeder, T. Cold Spring Harb. Perspect. Biol. 2012, 4, 1-18.

(30) Velten, L.; Haas, S. F.; Raffel, S.; Blaszkiewicz, S.; Islam, S.; Hennig, B. P.; Hirche, C.; Lutz, C.; Buss, E. C.; Nowak, D.; Boch, T.; Hofmann, W. K.; Ho, A. D.; Huber, W.; Trumpp, A.; Essers, M. A.;
Steinmetz, L. M. Nat. Cell Biol. 2017, 19, 271-281.

(31) Orkin, S. H.; Zon, L. I. Cell 2008, 132, 631-644.

(32) Cheraghi, M.; Asadi-Samani, M. Der Pharmacia Lettre 2016, 8 , 393-399.

(33) Udalamaththa, V. L.; Jayasinghe, C. D.; Udagama, P. V. Stem Cell Res. Ther. 2016, 7, 1-8.

(34) Hasan, N. M.; Al Sorkhy, M. K. IJHM. 2014, 1, 18-21.

(35) Pawar, R. S.; Jain, A. P.; Kashaw, S. K.; Singhai, A. K. Indian J. Pharm. Sci. 2006, 68, 337-340.

(36) Mendi, A.; Yağci, B. G.; Kiziloğlu, M.; Saraç, N.; Yilmaz, D.; Uğur, A.; Uçkan, D. J. Appl. Oral Sci. 2017, 25, 515-522.

(37) Aksu, D. S.; Didin, M.; Kayikci, F. Revista Română de Medicină de Laborator 2012, 20, 47-57.

(38) Ferri-Lagneau, K. F.; Moshal, K. S.; Grimes, M.; Zahora, B.; Lv, L.; Sang, S.; Leung, T. PLoS One 2012, 7, 1-14.

(39) Samet, I.; Villareal, M. O.; Han, J.; Sayadi, S.; Isoda, H. Asian J. Biomed. Pharm. Sci. 2014, 4, 1-7.

Received September 5, 2018

Revised October 17, 2018

Accepted November 9, 2018 